\title{
Retain or Reject: The Adherence to the Kosher Laws in a Canadian City
}

\author{
John Cappucci ${ }^{1}$ (1)
}

Received: 28 September 2020 / Accepted: 17 July 2021 / Published online: 9 August 2021

(C) The Author(s), under exclusive licence to Springer Nature B.V. 2021

\begin{abstract}
This article investigates the Jewish community of Windsor-Essex's adherence to the kosher laws. In this study, 50 participants were interviewed to determine whether they consumed pork, shellfish, separated meat and dairy, purchased products with a hechsher, and dined at non-kosher restaurants. The interview results indicate a mixed position on pork and shellfish with a near majority consuming the latter. A plurality of participants ensured the separation of meat and dairy. There were few participants who only purchased products with a hechsher. All participants said that they will frequent non-kosher restaurants, but some noted that they will limit what they consume. To justify these results, the researcher argues that kosher adherence will correlate slightly with age, but more with the education level of the participant. The results should also be seen in light of the decline of the elite version of Judaism and increase in individual autonomy.
\end{abstract}

Keywords Kosher food $\cdot$ Kashrut $\cdot$ Judaism $\cdot$ Windsor $\cdot$ Canada

\section{Introduction}

Diner (2001), a historian of American Jewry, states that "Judaism itself put food in the foreground" (178). The rationale for this statement is the kosher laws or kashrut which are intended to regulate the Jewish diet. Since the specifics of kashrut are not commonly understood, there is space available for Jews to interpret the kosher laws based on their own understanding. These individual interpretations will affect one's decision either to retain or reject the kosher laws in their own lives. Keeping the

This research was possible though the kind support of the Stephen A. Jarislowsky Chair in Religion and Conflict at Assumption University in Windsor, Ontario. A community-wide lecture on these results and Jewish religiosity in general was held in 2019. I also thank the three anonymous peer reviewers for their valuable comments.

John Cappucci

jcappucci@assumptionu.ca

1 Assumption University, 400 Huron Church Road, Windsor, ON N9C 2J9, Canada 
kosher laws is a matter that requires more study, particularly as it applies to contemporary Canadian Jewish life.

The primary question that concerns this article is what is the current level of adherence to the kosher laws among the Jews of Windsor-Essex County? This main question spurs other related questions: Which kosher food practices are largely followed? Which practices have been marginalized? To what degree do people eat treyf or non-kosher foods, and how is that rationalized? Is there a correlation between the participant's kosher practices and demographic factors, such as age or education level? In 2019, a sample of 50 members from this community were interviewed about their religious practices and beliefs. This study was entitled, Progressives and purists: A study of religiosity in a Canadian-Jewish community. The study used eight indicators to measure religiosity, namely belief in God, prayer, the Sabbath, congregational activities, holidays, kashrut, the mitzvot, and the World to Come. An article on the first three indicators, namely belief in God, prayer life, and Sabbath observances, was published in Canadian Jewish Studies (Cappucci 2020). The kosher laws will be the sole focus of this article given their unique expressions among this sample.

The article begins with an overview of the Jewish community of Windsor-Essex with emphasis on the institutions and kosher options in the area. The literature review surveys the major topics and debates within the subject of Jewish foodways. The few sources on keeping kosher in Canada have also been included. The methodology section outlines the interview process along with a tabular list of the participants' demographics. To discover the degree to which the kosher laws are observed, participants were invited to answer five questions on the following topics: consumption of pork and other non-kosher land animals, consumption of non-kosher seafood, mixing meat and dairy, purchase of only hechshered products (i.e., those certified as kosher by a formal organization with this purpose), and dining at non-kosher restaurants. The article will present the responses as percentages along with comments offered by the participants. In reference to hypotheses, I have arranged these five questions in order of what I perceive to be an increasing level of difficulty of adherence, suspecting that it is easier to avoid eating pork and shellfish than it is to separate meat and dairy. The former requires simple avoidance, whereas the latter requires one to have separate housewares, appliances, and kitchens. Along with the difficulty associated with keeping fully kosher, I argue that the participant demographics, particularly age and education, need to be taken into consideration, as they affect adherence levels. It is believed that participants who are younger and more educated will be less inclined to adhere to kashrut in comparison to those who are older and less educated.

\section{Jewish Windsor}

Windsor-Essex is the southernmost region in Ontario and by extension Canada as well. It is comprised of a population of 398,953 people as per the 2016 census (Statistics Canada 2017). For demographic purposes, the county is divided into a Census Metropolitan Area (CMA) consisting of the City of Windsor and the towns of 
LaSalle, Lakeshore, Tecumseh, and Amherstburg all within the County of Essex. Within this CMA, there are 1515 Jews making the area the seventh largest Jewish community in the province of Ontario (Shahar 2014: 84). The community may not be the largest in the province, but it does have a long history.

The Jewish community of Windsor traces its origins to the 1790s with the arrival of the Montreal merchant Moses David (1768-1814) (Plaut 2007: 21). After David's death, there was a lack of Jews in Windsor until a migration came from Poland, Russia, and Lithuania (Plaut 2007: 40). The oldest Jewish religious institution that exists in Windsor is the Orthodox synagogue that Shaarey Zedek founded in 1893. The synagogue no longer has a building, and its community worships with the next oldest Jewish religious institution, Congregation Shaar Hashomayim. The "Shaar" is a Modern Orthodox synagogue founded in 1929. Its building is one of the most iconic edifices in the city and a smaller replica of the historic Shaar Hashomayim in Montreal. The two Orthodox synagogues remained the centers of Jewish worship in Windsor for decades until the foundation of Congregation Temple Beth El in 1960. The Reform temple was initially under the leadership of the founder of Humanistic Judaism, Rabbi Sherwin Wine (1928-2007). Lastly, the Chabad Jewish Centre in Windsor is particularly engaged with university students. These four religious institutions are complemented by more secular organizations. The Windsor Jewish Federation and Community Centre (WJFCC) was established in the 1950s. Today, the WJFCC has several amenities and programs, including a senior's living residence, a children's summer camp, and educational opportunities. However, the most relevant facility for this study is Mazal Tov Kosher Cuisine, which resides within the WJFCC, under the supervision of Rabbi Sholom Galperin.

Before the end of November 2019, Mazal's served as Windsor's sole kosher restaurant. Now, Mazal's no longer functions as a restaurant. However, it is available for kosher catering for special occasions and holidays. In 2021, Mazal's began offering kosher meals for pickup every Friday. Other than Mazal's, there are no kosher delis, bakeries, or butcher shops in the area. Those who wish to keep a vague semblance of kashrut while eating out may choose to eat at non-kosher restaurants by selecting vegetarian and vegan dishes. Windsor-Essex does have several vegan restaurants to choose from, including Carrots N' Dates, Healthy Mama, and Globally Local. While these vegan restaurants present members of the Jewish community with an option, they are not a substitute for a formally certified kosher restaurant. If individuals wish to enjoy a kosher dining experience, Greater Detroit is home to many kosher restaurants. However, as will be discussed later in this article, there are a few challenges to crossing the border, particularly during the COVID-19 pandemic.

The absence of kosher restaurants should not render the impression that kosher food is not readily available in Windsor-Essex. The major corporate grocers in the city, such as Metro, Real Canadian Superstore, and Zehrs, all sell kosher foods. These stores all contain many hechshered processed products, such as canned goods, grains and cereals, oils and condiments, and beverages. Typically, in its weekly bulletin, Shaar Hashomayim will disseminate a flyer from Metro advertising various kosher products. While the flyer is beneficial for those seeking kosher foods, the flyer itself is from Toronto, meaning that not all products advertised may be available in Windsor, particularly milk and meat products. If individuals are adamant about 
accessing a wide selection of kosher products, Greater Detroit does have kosher supermarkets, such as One-Stop Kosher. Again, like in the case of restaurants, travelling to the United States may be challenging during the pandemic. It is fortuitous that face-to-face interviews were employed, as information on the community's kosher situation would not have been obtained as easily through other methods. This research will help to advance two bodies of academic literature, namely the growing literature on Jewish foodways and the specific studies on kashrut in Canada.

\section{Jewish Foodways: History, Theories, and Literature}

In their introduction to Global Jewish foodways: A history, Cinotto and Diner (2018) explain that Jewish studies played a significant role in cultivating academic interest in the subject given the distinct Jewish perspective on food (3). The authors note that this interest can be seen in the works of Claude Lévi-Strauss, Mary Douglas, and Marvin Harris (3-4). Despite the centrality of food in religion, religious studies originally ignored food studies, allowing other disciplines like anthropology and sociology to make the initial scholarly contributions (Norman 2012: 409). Eventually, religious studies realized the importance of food, particularly the fact that a religion's official regulation on food needed to be complemented with studies that explore the adherent's "lived" or actual experiences with food (Dallam 2014: xix). The difference between a religion's scriptural position on food and the actual experiences of its followers has prompted competing questions on individual autonomy.

The notion of individual autonomy is a subject of central importance in modern Jewish thought and of relevance to this study of kosher adherence. A leading theologian in the Reform tradition, Eugene Borowitz (1984), argues that a key concept to emerge from the Jewish Emancipation was the "autonomous self" (40). Borowitz explicates that following Emancipation, Jews took "an autonomous relation to Jewish law" (1984: 47), meaning that there is scope for the individual to include or exclude aspects that are relevant to them. When deciding, individuals could consider the teachings in the Torah, their desire to form a sense of solidarity with the Jewish community, or their own interest in keeping kosher. The increased role of the individual in making autonomous decisions needs to be considered in light of a bipartite division of Judaism.

The subject of kashrut can be understood differently based on whether one sees the concept as a matter of elite religion or folk religion. The distinction between the two has entered Jewish studies by way of the political scientist Charles Liebman. Liebman states that elite religion is comprised of the official beliefs and practices of the faith that the religious leadership puts forward as "legitimate" (Liebman 1973: 46). In contrast, Liebman notes that folk religion seeks the "sanctification of certain social, economic, or even sexual activity which elite religion refuses to legitimize" (1973: 47). The kosher laws may be placed within this dichotomy between elite and folk religion. The elites or the rabbinical authorities may require that Jews adhere to some or all aspects of kashrut given its perceived importance in Judaism. The religious leadership derives its authority to make pronouncements on diet from the relevant passages of the Torah, Talmud, and other revered works. In contrast, a folk 
religion version of Judaism may have an alternative attitude to kashrut that deviates from the established norms. For example, from the perspective of elite religion, shellfish must not be consumed. It certainly must not be cooked using household stoves or served with household dishware. The folk religion approach might make an accommodation by suggesting that shellfish could be brought into the home, but only consumed on disposable paper plates. Folk religion does not have an "elaborate theology" that justifies its beliefs and practices therein (Liebman 1973: 47). In other words, if the Torah forbids the consumption of shellfish, then how does it become suddenly permissible when it is served on a paper plate? This question can be answered by briefly reviewing the three major branches of Judaism and their divergent opinions on keeping kosher.

The question on one's branch of Judaism could lend itself to influencing one's devotion to the kosher laws. After tabulating each participant's branch of Judaism, the sample was discovered to be $30 \%$ Reform, $40 \%$ Conservative, $4 \%$ Orthodox, and $26 \%$ as non-affiliated with these major branches or affiliated with a small branch of Judaism. The three major branches of Judaism represented in this sample, namely Reform, Conservative, and Orthodox, have different stances on the kosher laws, requiring a brief overview of each.

Historically, the Reform branch did not emphasize the importance of the dietary laws in modern life as evidenced in the movement's early doctrinal framework, The Pittsburg platform (1885). While the signatories of The Pittsburg platform suggest that the dietary laws are an antiquated concept that have little value in the modern era (Principle 4), the Reform movement's position has warmed to the idea of kashrut. In Gates of mitzvah: A guide to the Jewish life cycle (1979), Reform Judaism now stresses the availability of "options" whereby Reform Jews are welcome to incorporate aspects of kashrut that fit into their lifestyle (132). This progressive position on kashrut flows from Reform Judaism's stance on religious autonomy. In short, Reform Jews "are expected to explore the tradition and come up with their own individual religious sensibility, embracing certain practices as religiously meaningful while rejecting others as redundant or antiquarian" (Kaplan 2013: 101). This wide degree of latitude is noticeably reduced when considering another major branch of Judaism.

The Conservative branch has long maintained its devotion to tradition while having an opening for change (Dorff 2018: 7). The landmark document Emet ve'emunah: Statement of principles of Conservative Judaism (1988) recognizes that "no one can perform all 613 mitzvot," leading to the conclusion that the branch may make some concessions (46). The Conservative branch does permit a few exceptions to a strict adherence to kashrut, particularly with wine, fish, and cheese (Fishkoff 2010: 273). In addition, Marshall Sklare, a prominent figure in the sociology of American Jewry, notes that the Conservative Jew "eats out" (1972: 203). The branch does allow a degree of "individual discretion" when Conservative Jews eat at nonkosher restaurants (Elazar and Geffen 2000: 83). For example, the Conservative Jew might eat lamb gyros without tzatziki sauce at a Greek restaurant. The meal itself neither contains proscribed foods like pork or shellfish nor does it mix meat and dairy. Nonetheless, because the meal is prepared in a non-kosher kitchen, served on non-kosher plates, and eaten with non-kosher utensils, it is treyf. However, for 
others, this treyf is actually considered a "kosher-style" meal. While a kosher-style meal will not contain the major forbidden foods or combinations, it has not been prepared under the strict supervision of a kosher certification agency (Deutsch and Saks 2009: 49). A meal that is strictly prepared according to kashrut in a certified facility may not be necessary for the Conservative Jew but would be essential for the most traditionalist branch of Judaism.

The Orthodox branch views the Torah and other scriptural works as "divinely revealed and immutable" (de Lange 2010: 72). Unlike the possibility for options for Reform Jews or the exceptions for Conservative Jews, Orthodox Judaism is "beyond comprise or even the appearance of compromise" (Liebman 1965: 39). Considering the authority of the Torah, the Orthodox Jew has a reduced degree of individual autonomy when it comes to a host of matters, including kashrut. The divergent positions on kashrut between the three major branches may give the impression that the three could not enjoy a meal together. However, an iconic and popular symbol of Jewish cuisine in North America might afford a common space for all.

The traditional Jewish delicatessen offers Jews the opportunity to enjoy a meal with family and friends. Ted Merwin delivers a historical and sociological overview of the Jewish delicatessen in the United States with a focus on the boroughs of New York City. At one point, the delicatessen served as an eclectic space bringing together Jews from various classes, national backgrounds, and religious perspectives (Merwin 2015: 7). In time, this cuisine would become unattractive to the kosherminded Jew. Sax (2010) notes that many New York delis served "flagrantly treyf food" with the most infamous and popular being the Reuben sandwich combining Swiss cheese and corned beef (32). Unfortunately for connoisseurs, this idyllic space started to decline significantly resulting in only a handful of kosher delis remaining in the center of American Jewry (Merwin 2015: 167). This trend is strengthened when considering the complete absence of kosher delicatessens, restaurants, butchers, and grocery stores in Windsor-Essex. Without kosher dining options open to them, the Jews of Windsor-Essex might turn to cuisine that may contain treyf. This possibility might indeed be the case, but one should not neglect the importance of the Jewish home in maintaining kashrut, particularly with the help of cookbooks.

It may be challenging for Jews in Windsor-Essex to keep kosher when dining in the community, but adhering to kashrut is noticeably simpler in the home. There is a small but growing body of literature on Jewish cookbooks and their role in Jewish identity, foodways, and communities. One phenomenon within Jewish communities was the charity cookbook. Barbara Kirshenblatt-Gimblett (1987) explains that at the beginning of the twentieth century, the majority of Jewish American cookbooks contained treyf recipes (8). Her explanation for the inclusion of unkosher recipes is that most cookbooks were published by Reform Jews who saw treyf as an "ideological issue" (8). The question is whether the presence of treyf in charity cookbooks would also appear in Jewish Canadian cookbooks.

In the past decade, recent studies have emerged that examine Jewish Canadian cookbooks, namely among the Toronto and Montreal communities. Eidinger (2012) explores a popular Jewish Canadian cookbook called A treasure for my daughter: A reference book of Jewish festivals with menus and recipes. Written by a Montreal chapter of Hadassah-WIZO in 1950, with several subsequent printings, the 
cookbook seeks to exemplify the values of the middle class Jewish Canadian women who sought to connect to the traditions of ancient and contemporary Israel instead of those from Eastern Europe (189). In A treasure for my daughter (1958), the traditional Jewish dishes have been complemented with new North American additions. These new recipes do not appear to contain treyf, as substitutions have been made for typically unkosher dishes. The willingness to expand the palate to North American foods appears to be a trend in these early Jewish Canadian cookbooks.

In her analysis of The Naomi cook book published from the late 1920s to 1960 and composed by Toronto's Hadassah-WIZO, Trojan (2020) suggests that this cookbook exemplified an "integration narrative" combining Jewish and Canadian values in an upper-middle-class milieu (35). The recipes included in The Naomi cook book were all kosher, helping to solidify the Jewish identity of the authors and readers (37). This cookbook is confirmation that one could be a kosher observant Jew while still adopting Canadian cultural practices. A question that remains is how far Jewish communities will go in order to integrate? In other words, will Jewish communities eventually abandon kashrut and move onto another cuisine as time progresses?

Gross (2019) proposes an answer to this question by stating that the "studies of Jews and food begin, but never end, with the study of kashrut" (2). The most popular expansion of the Jewish palate is to Chinese cuisine. In Gaye Tuchman and Harry Gene Levine's groundbreaking study on the reasons why New York Jews have a predilection for Chinese cuisine, the authors rationalize this penchant by proposing that Chinese food is treyf but specify that it is "safe treyf" (386). The rationale for this appellation is that the preparation of Chinese cuisine involves "cutting, chopping, and mincing" which in turn "disguises the tabooed ingredients" (389-390). In short, the concealment of pork in a wonton or hiding shrimp in a spring roll is more acceptable than a stack of baby back ribs or a plate of linguine with clams. Tuchman and Levin's discovery implies that Jews are willing to transgress the boundaries of kashrut to a degree. Since Tuchman and Levin's work, other studies have explored how diversity is incorporated into the Jewish diet such as Bahloul's (1995) ethnography of North African Sephardic Jews living in France, Steinberg and Proust's (2011) study of Jews in the American Midwest, and Marcie Cohen Ferris's (2018) exploration of the foodways of Jews in the Southern United States. These studies have contributed to the scholarship on Jewish foodways by expanding the contours of the subject to include a more diverse perspective. However, the conspicuous issue with these three studies is that they do not focus on foodways among Canadian Jewish communities.

\section{Kosher Canada}

The scholarly literature on kashrut in Canada can be classified into two groups: historical and applied. Within the historical group, there are a limited number of relevant works that explore Jewish dietary practices outside of the two centers of Judaism in Canada, namely Montreal and Toronto. The applied research presents quantitative data on a host of topics, often, though not always, including kosher food. The issue with this applied research is that the data is dated stretching back 
several years. Despite its limitations, the literature is still worth reviewing, as it showcases how keeping kosher has changed over time in Canada. Robinson's (2007) book on the historical role of the Ashkenazi Orthodox rabbinate in Montreal includes an intriguing chapter on the "Kosher Meat War" (103) in 1920s Montreal. The principal belligerents were the Va'ad ha-'Ir or Jewish Community Council and the Va'ad ha-Kashrut (60). Robinson shows that the causes of this conflict revolved around personalities, power, and prices (103-105). The war escalated to the point that it witnessed the use of personal threats, enforcers, and physical assaults (106). The matter was pacified by a Quebec court's ruling that the Va'ad ha-'Ir could not exert control over the kosher food industry (114). The power wielded by kosher certification organizations does not appear to have the same presence as it once did. In Windsor-Essex, kosher monitoring rests with one Chabad rabbi who acts as the mashgiach or supervisor of the sole kosher cuisine service in the county. The rabbi's services are also solicited when the community celebrates the annual Negev Dinner to support the Jewish Nation Fund (JNF). Before the COVID-19 pandemic, these celebrations would take place at a local Italian hall thus requiring extra koshering given the presence of non-kosher foods. Outside of these times, the responsibility for keeping kosher rests with the individual. This autonomy might present individuals with opportunities to consume treyf, but might have the opposite effect with individuals trying to keep kosher in creative ways, particularly in the current center of Canadian Judaism.

Toronto is home to the largest Jewish population in the nation, with approximately 188,710 Jews (Shahar 2014: 52). One of the significant advantages of living in a major city for any religious or cultural community is the access to specialty products that might not be available in smaller communities. Diamond (2002) argues that the spread of "consumerist culture" afforded Orthodox Jews in Toronto with ubiquitous opportunities for keeping kosher (489). He reports that Orthodox Jews in suburban Toronto embraced a "kosher lifestyle" that took on a "religious-materialist orientation" resulting in the proliferation of a host of kosher products and amenities (489). This way of life resulted in the demand for imported kosher American and European wines, pizzerias, hotels, and even vacations (496-502). While this Orthodox Jewish community may no longer be content in matzah ball soup, that does not indicate that they are willing to abandon kashrut entirely. Diamond's findings support the conclusion that Orthodox Jews are willing to go beyond the traditional foodways but only within the confines of kashrut. While Diamond does present a snapshot of how one Jewish community keeps kosher, it is unlikely that Diamond's thesis will apply to non-Orthodox communities in Canada. In reference to the Jewish community of Windsor-Essex, Diamond's research will have limited applicability as only two participants in the sample identified as Orthodox. The diversity within this sample will present an opportunity to study the kosher practices of Jews from various branches, including those who do not identify with a branch.

One work that gives some insight into the kosher practices of various Jewish branches is Charles Shahar and Tina Rosenbaum's Jewish life in greater Toronto: A survey of the attitudes \& behaviours of greater Toronto's Jewish community (2005). Shahar and Rosenbaum surveyed 654 Toronto Jews with the largest portion of the sample identifying as Conservative followed by Reform, Just Jewish, Orthodox, and 
other designations (13). Shahar and Rosenbaum found that only $22.4 \%$ were "strictly kosher" inside the house (27). In reference to dining at restaurants, they found that $10.2 \%$ were "strictly kosher" outside the house (27). In exploring the responses, the participants in the Windsor-Essex sample also made the internal-external distinction. While Shahar and Rosenbaum's study does offer a glimpse into Jewish Canadian devotion to kashrut, it does not specifically outline which aspects of the kosher laws are followed and which have been abandoned. Moreover, the data is over sixteen years old, prompting the need for a recent study on Canadian Jewry.

In 2019, Robert Brym, Keith Neuman, and Rhonda Lenton's 2018 Survey of Jews in Canada-Final report (2019) supplied a recent overview of Jewish Canada. One would expect that this comprehensive report would discuss some aspect of kashrut, but the report ignores the national community's observance of the kosher laws. Perhaps the authors believe that there is a disinterest in keeping kosher among Canadian Jews, particularly those from non-Orthodox branches. This situation may be the case, but further research that asks specific questions on kashrut in contemporary Canada is needed. A project on keeping kosher in small Canadian cities would be a step in the right direction.

\section{Methodology}

To obtain this data on kosher practices of the Jews of Windsor-Essex, I interviewed 50 members of the community. It might be suggested that an online survey could have been used here in place of interviewing. This suggestion holds merit and would have certainly saved time. However, I felt that an online survey might have some limitations in the case of this community. First, at the onset, I believed that given the relatively small size of the Jewish population in Windsor-Essex, it would not have been difficult to interview a reflective sample size of people. Second, in selecting online surveys, one is limited to obtaining information from only people who have the devices to complete the survey, such as a computer or smartphone. I was aware from the beginning that the Jewish community of Windsor had a sizable population that was older. According to the 2011 National household survey analysis: The Jewish population of Canada, $19.7 \%$ of Jews in Windsor-Essex are 65 years of older (Shahar 2014: 60). This statistic needs to be considered alongside the fact that only $71 \%$ of Canadian seniors (65 and older) have access to the Internet (Canada Internet Use Survey 2019). By employing an online survey, I would have excluded a considerable number of individuals from the potential participant pool.

There were three requirements to be a participant in this research project: personally identify as Jewish, live in Windsor-Essex, and be 18 years of age or older. The participants were recruited into this study with a call for participants poster placed at Jewish religious and cultural institutions, libraries, the university, and other locations. In addition, to avoid the dual role of the researcher asking participants to take part in the study and thus using his status as an acquaintance, Congregation Temple Beth El, Congregation Shaar Hashomayim, and the Windsor Jewish Federation and 
Community Centre emailed the call for participants and sent a letter of information to their members.

The participants were asked a few demographic questions. To better understand this sample, Table 1 outlines the sample's demographics, including gender $(\mathrm{M}=$ male and $\mathrm{F}=$ female); age; education $(\mathrm{HSD}=$ high school diploma, $\mathrm{SU}=$ some undergraduate, $\mathrm{CD}=$ college diploma, $\mathrm{UD}=$ undergraduate degree, $\mathrm{UDS}=$ undergraduate degrees, $\mathrm{PD}=$ professional degree, $\mathrm{GD}=$ graduate degree, and $\mathrm{UNK}=$ unknown); branch of Judaism ( $\mathrm{REF}=$ Reform, $\mathrm{CON}=$ Conservative, ORT = Orthodox, and OTH=other); and diasporic background (ASH=Ashkenazi, $\mathrm{SEP}=$ Sephardi, MIZ=Mizrahi; MIX = mixed, OTH=other). Generally, the average participant was in their sixties, college- or university-educated, coming from the Reform or Conservative branch and Ashkenazi.

Depending on the individual's responses, the interviews generally lasted from fifteen minutes to nearly two hours. However, the majority of interviews were completed in under one hour. In a few cases, family members wished to be interviewed with another family member, such as a spouse or parent and son or daughter. The researcher accepted this arrangement as some may feel more comfortable this way. For their time, participants received an $\$ 18$ gift card at the end of the interview. The next section will examine the results for each of the five questions on kashrut that were provided by the participants beginning with consumption of pork.

\section{Pork}

One of the most well-known rules from Biblical Judaism is that pork is not to be consumed by Jews. In the Book of Leviticus, God commands Moses and Aaron to convey to the Israelites that "the swine-although it has true hoofs, with the hoofs cleft through, it does not chew the cud: it is unclean for you. You shall not eat of their flesh or touch their carcasses; they are unclean for you" (Leviticus 11:7-8). The distaste for pork is carried over into the Talmud where the mere mentioning of the word is sometimes replaced with the phrase "something else" or "davar achar" (Sanhedrin 26b:19).

The participants were asked whether they consumed pork products or any other non-kosher meats. The participants seemed to take this question to refer to pork as other non-kosher meats. The participants appeared to be divided into two major groups, namely those who avoid pork and those who consume it. In responding to this question, $42 \%$ of participants stated that they avoid pork. Just over one-third or $34 \%$ of participants admitted to eating pork. There were also $6 \%$ of participants who answered that they sometimes eat pork and $10 \%$ who rarely eat pork. In addition, $8 \%$ of participants noted that they were vegetarian and thus did not consume any type of meat.

Most of the participants tended not to offer detailed reasons for avoiding pork products. The motivation for this relative silence may have to do with the divisiveness of the subject. Since this participant community is split on the matter of pork, one might take this to reflect the entire community. If the issue is contentious, then criticisms against pork might offend family and friends who eat pork. 
Table 1 Sample demographics

\begin{tabular}{|c|c|c|c|c|c|}
\hline Participant & Gender & Age & Education & Branch & Background \\
\hline 1 & M & 64 & UD & $\mathrm{CON}$ & ASH \\
\hline 2 & $\mathrm{~F}$ & 60 & GD & $\mathrm{CON}$ & $\mathrm{ASH}^{*}$ \\
\hline 3 & M & 62 & PD & $\mathrm{CON}$ & $\mathrm{ASH}^{*}$ \\
\hline 4 & $\mathrm{~F}$ & 68 & UD & REF & ASH \\
\hline 5 & M & 72 & UD & ORT & ASH \\
\hline 6 & $\mathrm{~F}$ & 31 & UD & OTH & ASH \\
\hline 7 & $\mathrm{~F}$ & 78 & SU & $\mathrm{CON}$ & $\mathrm{ASH}^{*}$ \\
\hline 8 & M & 86 & UD & $\mathrm{CON}$ & $\mathrm{ASH}^{*}$ \\
\hline 9 & F & 68 & SU & OTH & ASH \\
\hline 10 & $\mathrm{~F}$ & 67 & UDS & CON & ASH \\
\hline 11 & F & 72 & UDS & $\mathrm{CON}$ & ASH \\
\hline 12 & $\mathrm{~F}$ & 68 & GD & REF & ASH \\
\hline 13 & M & 29 & UDS & REF & ASH \\
\hline 14 & M & 72 & GD & OTH & ASH \\
\hline 15 & M & 80 & UD & OTH & ASH \\
\hline 16 & $\mathrm{~F}$ & 75 & GD & OTH & ASH \\
\hline 17 & M & 85 & GD & REF & ASH \\
\hline 18 & $\mathrm{~F}$ & 24 & UD & OTH & ASH \\
\hline 19 & $\mathrm{~F}$ & 20 & SU & REF & ASH \\
\hline 20 & $\mathrm{~F}$ & 25 & UD & REF & OTH \\
\hline 21 & $\mathrm{~F}$ & 64 & GD & REF & ASH \\
\hline 22 & $\mathrm{~F}$ & 79 & $\mathrm{CD}$ & OTH & ASH \\
\hline 23 & $\mathrm{~F}$ & 64 & UD & $\mathrm{CON}$ & $\mathrm{ASH}^{*}$ \\
\hline 24 & M & 68 & SU & CON & $\mathrm{ASH}^{*}$ \\
\hline 25 & $\mathrm{~F}$ & 79 & $\mathrm{CD}$ & $\mathrm{CON}$ & ASH \\
\hline 26 & $\mathrm{~F}$ & 61 & UD & CON & $\mathrm{ASH}^{*}$ \\
\hline 27 & M & 34 & $\mathrm{SC}$ & $\mathrm{CON}$ & $\mathrm{ASH}^{*}$ \\
\hline 28 & $\mathrm{~F}$ & 75 & UDS & OTH & $\mathrm{ASH}^{*}$ \\
\hline 29 & M & 83 & UDS & REF & $\mathrm{ASH}^{*}$ \\
\hline 30 & M & 51 & UD & REF & ASH \\
\hline 31 & M & 61 & UD & $\mathrm{CON}$ & ASH \\
\hline 32 & F & 38 & GD & CON & ASH \\
\hline 33 & M & 71 & PD & OTH & ASH \\
\hline 34 & F & 58 & GD & OTH & MIZ \\
\hline 35 & $\mathrm{~F}$ & 20 & SU & REF & ASH \\
\hline 36 & F & 67 & GD & OTH & MIX \\
\hline 37 & $\mathrm{~F}$ & 80 & HSD & $\mathrm{CON}$ & SEP* \\
\hline 38 & M & 50 & UDS & CON & SEP* \\
\hline 39 & $\mathrm{~F}$ & 88 & UNK & ORT & ASH \\
\hline 40 & M & 60 & GD & CON & ASH \\
\hline 41 & M & 65 & GD & REF & ASH \\
\hline 42 & F & 72 & UDS & CON & ASH \\
\hline 43 & $\mathrm{~F}$ & 65 & UDS & REF & ASH \\
\hline
\end{tabular}


Table 1 (continued)

\begin{tabular}{llllll}
\hline Participant & Gender & Age & Education & Branch & Background \\
\hline 44 & F & 59 & GD & REF & ASH \\
45 & M & 70 & UD & OTH & ASH \\
46 & F & 70 & GD & CON & ASH \\
47 & F & 53 & UD & REF & OTH \\
48 & F & N/A & GD & REF & MIX \\
49 & M & 55 & GD & CON & ASH \\
50 & F & 87 & HSD & OTH & ASH \\
\hline
\end{tabular}

*Interviewed two family members, such as couple or parent and son or daughter

A condemnation of pork might incite a heated debate that could sour relationships. The participants are uncertain about the researcher's own dietary habits. Therefore, engaging in a long diatribe on the impurity and unhealthiness of pork might potentially offend the researcher. While strong opinions may have not emerged, participants did share some information about their positions on pork.

There was one participant who was concerned about avoiding pork products. The participant shared that she or he will "look at the ingredients to ensure no pork" (Participant 15). The argument may be made that the participant could simply look for a hechsher to ascertain if the product is kosher. However, if the product is produced by a local bakery, then hechshers might not be available. The participant went on to note that he or she was especially concerned if the product "might have lard" (Participant 15). If someone is not aware that lard is derived from pig fat, then this could be a problem for the kosher-minded Jew. There were other participants who were less concerned about possible pork by-products and more concerned about the sanctity of their homes. When asked about the consumption of pork, one participant said "yes, but not in the house" (Participant 8). Later in the interview, the participant disclosed why he or she ate kosher at home but dined on treyf outside the home. The participant revealed that he or she kept kosher in the home to ensure that a favorite relative would come and visit (Participant 8). The participant shared that this relative, who strictly kept kosher, would not visit if he or she was entering a non-kosher home (Participant 8). This dynamic of maintaining a kosher home on one hand while eating treyf outside the home would be expressed again. However, in the next case, the reasoning is different.

When asking the question about pork, one couple said that while they rarely consume pork, it would occur "only outside the home" (Participants 23 and 24). Again, later in the interview, the rationale for this distinction between the home and outside the home becomes more apparent. One member of the couple noted that when it comes to treyf, they "never would cook or put it on their dishes" (Participant 23). However, the participants did concede later in the interview that sometimes treyf might enter the home. If it did, they would use "paper plates" (Participants 23 and 24) rather than their regular household dishware. The justification for disposable dishes is that paper plates can be discarded after use, thus ensuring that the household dishware is not contaminated. Using paper plates to eat treyf seems to place 
greater value on what one places on the household dishware than what one puts in one's body. The logical argument would be that the body should be a temple of purity and be the focus for the individual Jew. Inanimate objects, such as dishes and utensils, should always be secondary. This position seems to ignore the importance of the Jewish home. In his introduction to Judaism, Robinson (2016) declares that, "The synagogue is one of the two centers of Jewish life. The home is the other" (51). This statement is correct given the myriad of events that take place in the Jewish home from the brit milah or circumcision to shiva or the period of mourning. The sanctity of the home should not give the impression that treyf never enters the household kitchen. Bahloul (2016) better describes the distinction between inside and outside by referencing the example of Sephardic North African Jews in France. Bahloul explains that kosher food is associated with "home/sacred/traditional," whereas nonkosher foods are "non-domestic/secular/French" (105). If non-kosher foods enter the home, they were prepared outside of it so as to not contaminate houseware (105). The participants who avoid bringing treyf into the home or place it on disposable dishware exemplify the importance of preserving the sanctity of the Jewish home from animals that are seen as unclean. Jews are not only confronted with protecting themselves and their homes from pork. The laws of kashrut provide interdictions against other animals, including those that dwell in water.

\section{Shellfish}

In the verses following the condemnation of unclean mammals, the Torah differentiates between clean and unclean sea creatures: "These you may eat of all that live in water: anything in water, whether in the seas or in the streams, that has fins and scales-these you may eat" (Leviticus 11:9). This passage begs the question as to why fish with fins and scales are permissible to eat. In his work, Eat and be satisfied: A social history of Jewish food, John Cooper (1993) cites the medieval Catalan philosopher Nachmanides (c. 1194-1270) who suggests a reason for this commandment: "Now the reason for specifying fins and scales is that fish which have fins and scales get nearer to the surface of the water and are found more generally in fresh water areas" (cited in Cooper 1993: 18). This anecdotal answer implies that fish that approach the top of the water can expel any harmful pollutants (Eisenberg 2004: 658). While these fish may approach the surface of the water, there are many other sea creatures that do not have this ability. The Torah clearly outlines the types of seafood that are prohibited to Jews: "But anything in the seas or in the streams that has no fins and scales, among all the swarming things of the water and among all the other living creatures that are in the water-they are an abomination for you" (Leviticus 11:10). This passage can be interpreted to prohibit eating crustaceans, such as lobsters, shrimps, and crabs, and mollusks, such as clams, oysters, mussels, and squid. The Torah and Talmud do not reveal why these seafoods are proscribed. The absence of a rationale may lead to a divided position on seafood.

The participants were slightly more inclined to eat non-kosher seafood over pork. A near majority or $50 \%$ of participants noted that they eat non-kosher seafood. There were two participants who expressed that they sometimes eat it, with another four 
participants indicating that they rarely consumed shellfish. There was one participant who is allergic to shellfish. The higher propensity for the participant community to eat non-kosher seafood could be understood as a matter of probability. Shellfish can include numerous types of species which results in more opportunities to eat them. For example, if one were to attend a reception with various hors d'oeuvres, one could be presented with shrimp cocktail, fried scallops, and crab canapes all at the same event. Nevertheless, despite the many possibilities for eating non-kosher seafood, this sample contains a sizable portion of participants who avoid it.

The $36 \%$ of participants who do not consume non-kosher seafood tended again not to offer much explanation for their responses. One participant avowed that he or she is "strongly against shellfish," but did not disclose why he or she has taken this position (Participant 18). Like in the case of pork, the participants may not have wished to potentially offend the researcher by engaging in a harangue on shellfish. One generally held assumption is that shellfish are unhealthy to eat. This belief was expressed by one participant who noted that shellfish are "bottom feeders" (Participant 22). This comment is based on the belief that some non-kosher seafood inhabits the bottoms of oceans and lakes and consume matter that other larger species avoid. This matter can consist of pollutants that may prove harmful to larger species. This participant seemed to be aware of this issue considering that he or she declared that he or she was "health crazy" (Participant 22). This participant's decision to avoid non-kosher seafood is not based on religious ordinances, but rather an overall concern for one's health. The rules on shellfish seem simple. To observe them, one simply needs to avoid these foods. There are no added practices that need to be followed. However, while prohibitions against certain types of food are all integral components of kashrut, they are arguably the easier rules to follow. The next section explores an aspect of kashrut that transcends simply abstaining from certain foods by exploring a facet of the kosher laws that requires the constant separation of two major food families.

\section{Meat and Dairy}

One of the more challenging kosher laws to follow is the separation of meat or basarlfleishig and dairy or chalev/milchig products. This practice is derived from a verse in the Torah that is repeated three times. In this repeated passage, God commands the Israelites that they "shall not boil a kid in its mother's milk" (Exodus 23:19; Exodus 34:26; Deuteronomy 14:21). The Talmud teaches that this the passage is stated three times to prevent three types of actions: "One verse serves to teach the prohibition against eating meat cooked in milk, and one serves to teach the prohibition against deriving benefit from it, and one serves to teach the prohibition against cooking meat in milk" (Chullin 115b: 6). This passage supports the conclusion that the commandment against mixing meat and dairy is more complex.

The rule against mixing meat and dairy is more than ensuring that the two are not cooked together. The prohibition has been extended to include meat meals that may be topped with dairy products after cooking, such as pasta with Parmesan cheese and meat sauce and cheeseburgers. The requirement to separate meat 
and dairy is not solely confined to ensuring that one's food does not contain the two ingredients together. It also encompasses having separate dishware and utensils for meat and dairy. Kraemer (2007) claims that this stricter interpretation only gained prominence in the modern era, particularly around the eighteenth century (120). In some Jewish homes, this sterner understanding continues to have prominence, leading kosher-minded Jews to have two separate sinks, sponges, and kitchens (Deutsch and Saks 2009: 113). For those particularly dedicated to the separation, some may wait several hours before consuming a dairy product after they have consumed a meat one. The time one must wait ranges based on one's background and branch of Judaism with Orthodox Jews waiting six hours and Conservative Jews waiting half that time (Fishkoff 2010: 14). In contrast to separate utensils and dishware, Kraemer states that this practice of waiting was not as popular and started to dwindle in fidelity as time progressed (120). The waiting period was mentioned during the interviews along with a wide range of ways the separation of meat and dairy is followed by participants.

The participant sample was almost evenly divided on the practice of separating meat and dairy with $42 \%$ adhering to the rule and $38 \%$ rejecting it. There was also a minority or $16 \%$ of participants who partially followed the practice. The remaining participants were vegetarians, thus rendering the question not applicable. There were various levels of observance among the participants who ensured the separation of meat and dairy. One participant who "used to do that" now only keeps "kosher style" (Participant 25). The kosher-style requirements are not as rigorous as those for kosher. It means that proscribed foods like pork and shellfish will not be used as ingredients and that meat and dairy will remain separate. The meat may not satisfy all the requirements of kashrut, but does not come from an unclean animal. The side dishes are not made with treyf, but may be obtained from sources that do not list a hechsher. The participant did expand upon what he or she meant by kosher style, noting that it is "meat or dairy-one or the other" (Participant 25). The idea given is that one consumes either a meat meal or a dairy meal. Given that the approach is kosher style, the degree of compliance may not be as meticulous as those who follow strictly kosher dietary rules.

The next level of commitment to this rule appeared to be participants who would not consume meat and dairy within the same sitting. One participant noted that he or she will not have meat and dairy "at the same time" (Participant 23). The participant went on to clarify that he or she would not have a roast dinner followed by an ice cream dessert (Participant 23). This participant seems to be taking the position that meat and dairy should not be served in the same sitting let alone together in one dish and on one plate. There were other participants who took an even more strict approach. One participant shared that he or she will "wait three to four hours" (Participant 27) before eating meat after consuming a dairy product or vice versa. This waiting period is based on the belief that the taste and particles of meat may remain in one's mouth for a few hours after eating (Deutsch and Saks 2009: 113). There were only a few participants who followed the proscription against mixing meat and dairy by having separate dishes and utensils. These more scrupulous approaches should not render the impression that this rule cannot be partially followed to suit one's preferences and lifestyle. 
Of the $16 \%$ who indicated that they partially avoid mixing meat and dairy, one participant in this group noted that she does so because of upbringing (Participant 12). The participant shared that the rule is "still on my mind because I grew up that way" (Participant 12). This upbringing manifests itself still today, as the participant noted that "if a recipe calls for cream, then I will ignore it" (Participant 12). The role of one's upbringing cannot be discounted. There was another participant who stated that he or she will partially follow this rule "based on habit" (Participant 15). This response implies that the choice is an unconscious decision manufactured by years of conditioning. Nevertheless, the participant did say that he or she "will have a cheeseburger" (Participant 15) on occasion. From these two responses, one can conclude that the initial response is to try and avoid meat and dairy, but if that is not possible, then occasional deviations from the rule may be permitted.

In some instances, these deviations to the rule return to the inside-outside dichotomy described above when exploring participant responses to non-kosher seafood. One participant commented that he or she will maintain the separation in the home, even by dividing the dishwasher into a meat section and a dairy section (Participant 42). However, for this participant, the separation of meat and dairy only seems to apply in the home. The participant went on to share that at a restaurant, he or she might eat a dish that contains meat and milk, such as chicken Parmesan (Participant 42). This participant's response alerted me to the common practice of house rules and restaurant rules. However, more might be at play here than simply home versus restaurant rules. It seems that chicken may be an exception to the mixing of meat and dairy rule. One participant who tries to maintain the separation clarified that "chicken and milk is okay because scripture says about calf in mother's milk" (Participant 13). The participant is slightly incorrect with his or her interpretation, as the Torah mentions a kid or baby goat rather than a calf (Exodus 23:19; Exodus 34:26; Deuteronomy 14:21). However, the question that this participant's response provoked is whether chicken should be included in this prohibition. After all, chickens do not produce milk, so the argument that it is cruel to boil a child in his mother's milk would not apply. These types of rationalizations suggest that individuals are alone and left to their own devices in determining whether a meal would be considered kosher or not. However, in Judaism, there is a comprehensive system of food labelling that offers invaluable guidance for those seeking to maintain a kosher lifestyle.

\section{Hechsher}

The Hebrew term hechsher loosely translates into English to mean "supervision" (Blech 2008: 2). Today, a hechsher is a symbol affixed to a food product only after it has met the strict guidelines of a kosher certification agency (Robinson 2016: 258). Alongside the kosher certification agency's symbol, additional words or letters may be included to delineate if the product is dairy, meat, or pareve meaning neither meat nor dairy. There are many hechshers that one can find in Canada granted by several kosher certificating bodies such as the Orthodox Union (U), Kashruth Council of Canada (COR), and Montreal Kosher (MK). The question is whether the Canadian 
Jews included in this sample will purchase hechsher products or simply buy anything they wish.

During the interviews, participants were asked if they only purchase products with a hechsher. The sample results demonstrated that participants were not keen on limiting their purchases to only products with a hechsher. There were six participants or $12 \%$ who only purchase hechshered products. While it was predicted that only a few participants would strictly purchase hechshered products, it is still worthy to ask the question, as it could uncover the degree to which participants employ the hechsher system and the reasons for any exceptions.

The reasons for not adhering strictly to the hechsher system manifest themselves among participants who partially respect this practice. The $22 \%$ of participants who partially follow the hechsher system provided an array of conditions, foods, and times when they will purchase hechsher products. One participant noted that he or she will purchase hechshered products during Passover (Participant 9). The participant noted that he or she will ensure that khametz or the rising agents in oats, wheat, and rye are not used during Passover (Participant 9). It should be noted that hechshers are also included on foods that are approved for Passover, so the participant's response is relevant to the question. There were other participants who were not limited by the time of season, but rather by the type of product they were purchasing.

One participant provided a detailed response on what types of food he or she will endeavor to seek a hechsher on. The participant acknowledged that he or she is "less strict when it comes to dry goods" because these types of products usually have "less gelatin" (Participant 32). There is a concern for gelatin, as the product may contain animal fat derived from unkosher sources, such as pigs. The debate over unkosher animal byproducts has a long history and has been explored in detail with popular drinks and foods. In investigating the debate surrounding the use of unkosher derived products to make the essential gelatin for Jell-O, Horowitz (2016) notes that the product was permitted under the rabbinical argument of ponim chadashos meaning that the byproduct would undergo a complete chemical change rendering it a new product (56-57). The more Orthodox poskim or deciders of law, such as Rabbi Moshe Feinstein (1895-1986), rejected this line of argument, altering the trajectory of kashrut toward a more traditional stance (67). This change in opinion has caused some corporations to add a line that the product does not contain pork-derived gelatin. For example, Yoplait's Source Yogurt ( $0 \%$ milk fat) lists on the container "gelatin not sourced from pork" in bold letters. While it may put some Jews at ease, this statement is not a substitute for a hechsher. This participant informed me of the difficulty in obtaining kosher milk or chalev Yisrael in the city (Participant 32). The matter of limited kosher products in the area did reappear in the responses, particularly with meat. One participant said it was challenging to find kosher chicken in the city, as there appeared to be a limited supply at some of the major grocery stores (Participant 37). This experience is compounded by the lack of a kosher butcher in Windsor. The desire to have kosher meat prompted a few participants to note that they will travel across the border to Detroit to access a larger selection of kosher goods. One couple expressly noted that they will often shop at One-Stop Kosher in greater Detroit (Participants 2 and 3). The fact that participants must travel about 
30 minutes into another country to obtain kosher foods might have an impact on observing the dietary laws. For some, travelling into the United States is challenging, particularly if they do not have transportation, a passport, or American currency. Moreover, as of early 2020, the Canadian-American border remains closed to shoppers due to the COVID-19 pandemic.

With the difficulty in obtaining products with a hechsher, some participants noted that they will examine the ingredients of products before purchasing. One participant who partially buys hechsher foods declares that he or she will buy "as many as I can find with a hechsher," but "if it doesn't have banned things in it and it does not have a symbol, I will buy it" (Participant 11). For example, there may be locally baked apple turnovers with its ingredients listed on the package. It is doubtful that the turnovers have pork, shellfish, or mixed meat and dairy. Even though the product does not have a hechsher, the ingredients reveal that it will be acceptable though not kosher. Those who take the time to read the ingredients were in a minority, as most participants are not interested in following the hechsher system.

Nearly two-thirds or $66 \%$ of participants will not limit their purchases to only food products with a hechsher. This large percentage should not give the impression that participants who selected this response consume vast quantities of pork, shellfish, and other forbidden foods. One participant noted that he or she does "not necessarily" buy foods with a hechsher, but will look at the ingredients to ensure that the product does not contain pork or shellfish (Participant 42). This type of response seems more akin to the practice of "kosher style" that is practiced by some Jews. This response represented one of the more conciliatory answers among those who do not purchase hechsher products. This question seemed to be a sensitive topic, as it elicited one of the more vocal responses in the entire study.

In asking one participant whether he or she purchases only hechsher products, the participant used this opportunity to declare that "the dietary laws are preposterous" (Participant 17). This participant moved to further defend his or her statement with a sectarian-based response. The participant opined that the dietary laws were "an early way of separating the communities so not to socialize with each other" (Participant 17). If a Jewish family strictly heeds the dietary laws, it would not be possible to dine at the home of their Christian neighbors. However, the Jewish family is welcome to invite their Christian neighbors for Shabbat dinner. The importance of sharing a meal with individuals from different religious backgrounds cannot be discounted. It is an opportunity to learn about other traditions and build strong friendships. This question elicited criticism not only of the dietary laws, but also those who claim to practice them. In responding to this question on hechshers, one participant articulated that he or she could not "understand people who keep kosher at home and then eat everywhere" (Participant 43). The participant's response does prompt some questions. If one only purchases hechsher products, separates meat and dairy, has two sets of dishware, and even has two kitchens and then in turn decides to eat at a restaurant that handles pork, shellfish, and other proscribed substances, then what is the rationale? In other words, kosher at home and treyf on the town. This participant seemed to have had some foresight because later in the interview, participants were asked about whether they eat at non-kosher restaurants. 


\section{Kosher and Non-Kosher Restaurants}

The Father of Reconstructionist Judaism, Kaplan (1935) questioned the rationale for adhering to kashrut outside of the home, as he believes the point of keeping kosher is to foster a "Jewish atmosphere" within the home (441). Continuing with this thinking, one wonders about the purpose for maintaining kashrut at a restaurant if its purview resides exclusively in the home. In describing his own kosher practices at home, Weinfeld (2018), one of the leading scholars of Canadian Jewry, writes that "like many Canadian Jews, our dishes are reasonably kosher, but our stomachs are treif, or unclean" (287). This statement summarizes not only the age-old distinction between inside and outside kashrut, but also the potential trouble Canadian Jews might have in finding kosher restaurants, particularly in Windsor-Essex.

When the interviews were being conducted in 2019, there was one kosher restaurant in the entire county. By the end of the year, the restaurant closed, leaving Windsor without a formal kosher dining establishment. After the restaurant's closure, but even before, it would be probable that a great majority of participants would eat at non-kosher restaurants given the limited choices available. As of 2021, one kosher option remains, namely the kosher restaurant that has rebranded into a kosher catering service. Given that catering services often require the customer to provide notice and reservations, it would be challenging for one to satisfy their craving for a smoked meat on rye sandwich immediately. The catering service has begun to offer prepared kosher meals that can be stored in the freezer. While it is promising that prepared kosher meals are offered, individuals may wish more variety. The option in this case would be for the individual to make the sandwich at home. It is possible that a slim minority of participants will avoid non-kosher restaurants and cook for themselves to ensure that the kosher laws are followed. However, the Jews of Windsor-Essex have an alternative option in the form of Metropolitan Detroit.

The close proximity to a major American city does present the possibility that Jews in Windsor-Essex will travel across the border to enjoy a kosher meal. Greater Detroit has several kosher eateries spread out around the area from Jerusalem Pizza in Southfield (dairy) to Kravings in Oak Park (meat) to the Soul Cafe in West Bloomfield (dairy). The diversity of kosher cuisine is tempting, but as explained above, there are challenges, particularly now. The obvious issue is that the border is closed for nonessential travel due to the COVID-19 pandemic. The other issue revolves around the tolls to use the bridge or tunnel, added mileage costs, and the exchange rate, which at the moment does not favor Canadians. At the moment, it appears that Jews in Windsor-Essex have few options available for kosher dining.

The results showed that all 50 participants ate at non-kosher restaurants. This marked the first time in this study when all participants provided the same response. I was expecting that perhaps one or two participants would have indicated that they will only eat at kosher restaurants or at homes in which the host follows the dietary laws. The fact that all the participants eat at non-kosher restaurants should not convey the message that they have forgotten the dietary laws. This question's value is not that participants all eat at non-kosher restaurants, but rather how they attempt to maintain a semblance of kashrut at these restaurants. 
There were 43 participants who simply answered yes to this question without providing context to their responses. However, the remaining seven participants shared some thoughts on their dining experience at non-kosher restaurants. These participants all imposed restrictions on what they will consume. One participant admitted that he or she will eat "kosher-esque," meaning that he or she will have a "burger" but "no cheeseburger" (Participant 32). The participant will eat at non-kosher restaurants, but will not consume products that are treyf. The cheeseburger is certainly treyf, as it mixes meat and dairy. However, a burger, while probably not being made with kosher beef, is seen as less offensive. There are several other participants that impose more self-limitations when dining out. One participant specified that he or she will eat "chicken or fish [but] no beef" (Participant 38). Again, one notices that chicken seems to have a special status that makes it more acceptable in comparison to beef. The prospect that chicken is an exception is not shared by the remaining five participants who have placed stricter limitations on themselves. These five participants all affirmed that they would eat at non-kosher restaurants but will avoid meat. In some cases, the participants replied that they will typically consume fish. The choice of fish makes matters much simpler for the kosher-minded Jew given that fish is regarded as pareve. In selecting fish, one need not worry about mixing meat and dairy. For example, with a fish meal one could also enjoy a coffee with cream or dairy-based dessert. The fact that only seven participants had self-imposed limitations on what they will eat at non-kosher restaurants could be an indicator that the sample is not keen on adhering to the kosher laws. This conclusion could be supported when the responses to the other four questions are taken into consideration.

\section{Conclusion}

This article has summarized the responses to five questions on adherence to the kosher laws among Jews in Windsor-Essex County. Of the five questions, it appears that the participants do not follow the kosher laws in large numbers. To better compare the data from the five questions, I created the Kosher Adherence Scale. The responses for each of the five questions were rated on a scale from zero (not kosher) to one (fully kosher). Those who kept kosher to a degree received partial scores. There were five individuals who were either vegetarians or allergic to shellfish. Since these participants did not consume the proscribed products and in turn maintained the separation of meat and dairy, they were accounted as such. If all five scores are added together, the maximum possible score a participant can receive is five, indicating a fully kosher person. The table below summarizes the results for each of the five questions followed by a table that provides a description of the total scores (Tables 2, 3).

In aggregating the five scores, the sample's overall score is 1.90 out of 5 . This number indicates a low level of adherence to the kosher laws. This overall lack of observance merits some discussion. As the overview of each branch's position on kashrut demonstrated, the kosher laws are not a universally held requirement among all Jews. There are some Jews who see kashrut as an integral component of their faith that cannot be dismissed. Others see the kosher laws as a vestige of the past 
Table 2 Kosher adherence score by question

\begin{tabular}{ll}
\hline Question & Score $(0-1)$ \\
\hline Pork & 0.61 \\
Shellfish & 0.46 \\
Separation of meat and diary & 0.54 \\
Hechshers & 0.22 \\
Non-kosher restaurants & 0.07 \\
\hline
\end{tabular}

Table 3 Total Kosher adherence score range and descriptions

\begin{tabular}{ll}
\hline Total kosher adherence score & Description \\
\hline $0-0.99$ & Not kosher \\
$1.00-1.99$ & Mostly unkosher \\
$2.00-2.99$ & Minimally kosher \\
$3.00-3.99$ & Moderately kosher \\
$4.00-4.99$ & Significantly kosher \\
\hline
\end{tabular}

that has no basis in contemporary society. It is the job of the researcher to clarify as to why some Jews subscribe to the former opinion and why some accept the latter. To help with this explanation, I consider the sample's demographic differences, particularly age and educational background.

The first demographic characteristic that might help to provide insight into the sample's adherence level is age. The potential relationship between age and adherence levels has been explored in other scholarly works. For example, Joëlle Bahloul's study of the diasporic North African Jews in France discloses who is likely to eat kosher and who is likely to consume treyf. Bahloul's discussion of "clandestine meats" (1995: 489) or foods that are considered treyf is relevant. She discovered that the informants who consumed these foods where typically younger, from a higher social class, and had a desire for upward social mobility (1995: 489). Bahloul's findings that younger people are less inclined to keep kosher in comparison to their older counterparts is somewhat exemplified in the sample of Windsor-Essex Jews. The most kosher-minded participant in the sample was also the oldest with a total score of 4.5 out of 5 . This might discern a slight relationship between age and adherence to kashrut. In the rest of the sample, it was discovered that the most kosher-minded participants scored four or above on the adherence scale. Of the five participants who scored four or above, four of them were older than seventy years of age. However, this preliminary pattern is not maintained when more participants are compared.

To further determine if there was a relationship between age and adherence, I compared the youngest seven participants with the oldest seven participants. The youngest participants had an average kosher adherence score of 1.86, whereas the oldest seven participants had a score of 2.14. It would have been expected that the difference in adherence levels between the two age groups would have been drastically different. While age might not be useful in understanding the sample's 
practices, the participant's education might have an effect on their adherence levels to kashrut.

A large majority, or 41 out of 50 participants, hold tertiary credentials from college diploma to graduate degree. The sample's education achievement reflects the "extraordinarily high" level of education among Canadian Jews (Brym et al. 2019: 6). In 2017, the Pew Research Center took up the perennial question on whether there is a relationship between higher levels of education and lower religious belief and adherence. Among American Jews, the study revealed that there is a significant relationship between education levels and religious beliefs. For example, when asked the question, "How important is religion in your life?" $50 \%$ with a high school diploma or less responded "very important," whereas only $25 \%$ of the net college graduates selected this response (22). The relationship manifests itself again when participants were asked whether they believed in God. Of those with a partial or full high school education, 58\% stated that are "absolutely certain" in their belief in God (22). The level of adherence drops to $28 \%$ among the net college graduates (22). Both questions demonstrate that there is a significant difference in religious beliefs between those with post-secondary credentials and those without. Granted, there is a difference between believing in a deity on one hand and adhering to a religiously inspired dietary regimen on the other. It is in this gap that I seek to provide an answer.

The question now is whether varied education levels would affect one's devotion to keeping kosher. To answer this question, the participants were divided into two groups. The first group consisted of participants who completed college or university. The second group comprised the remaining participants who had completed some university or college, a high school diploma, or less. The first group held an average kosher adherence score of 1.13, indicating mostly unkosher dietary practices. The second group appeared to be more kosher-minded with an average kosher adherence score of 2.38. The difference of 1.25 between both groups is the most pronounced difference within the sample, adding some credence to the relationship between education and religious adherence. The Pew Research Center's A portrait of Jewish Americans (2013) discovered that there is a relationship between one's education and adherence to kashrut. This study showed that $41 \%$ of people with secondary credentials or less keep kosher, while only $17 \%$ of bachelor's degree holders follow kashrut (77). Within the Pew study, the percentage who adhere to kashrut continues to slightly decrease as one increases in educational credentials (77). While the results from the Pew study help to substantiate this sample's findings on the relationship between education and kashrut, they do not offer a possible explanation for this relationship.

The disparity between the two groups merits some discussion on the possible reasons for the difference. Perhaps a young man from Windsor was raised in a kosher home, but then left to attend university in a major city. There, he meets other Jews and non-Jews along with appetizing international cuisine. The new circle of friends and exciting foods influence his opinion on kashrut, causing him to ignore aspects or completely abandon a kosher diet. In addition, the young man's new environment is free from the strictures imposed during his upbringing by his parents. He has a newfound sense of individual autonomy that was not available at home. This prompts 
individuals to reflect on their own cultural and religious practices and how they compare with others from outside of the faith and from across the branches of Judaism. It seems that a future study exclusively investigating kosher adherence among college and university graduates is in order. This type of study could help to confirm this study's conclusions on the potential relationship between keeping kosher and education.

The results from this study indicate that keeping kosher is a complex matter that is best understood as a continuum rather than a dichotomy. The results demonstrate that the individual rather than an authority is the ultimate arbiter over one's diet. The sample shows that the individual has displaced Biblical and Talmudic ordinances, rabbinical authority, and traditions of yesteryear. With the increased sense of individual autonomy, the decline of elite religion, and the role of education, perhaps this sample is a microcosm of the overall decline in the observance of the kosher laws among Canadian Jewry. If this prediction is the case, then the "pots and pans" (Neusner 1988: 3) that were thought to have defined Judaism may have been put away into the cupboard.

Funding Stephen A. Jarislowsky Chair in Religion and Conflict.

\section{Declarations}

Conflict of interest The author declares that there is no conflict of interest.

\section{References}

A portrait of Jewish Americans: Findings from a Pew Research Center survey of U.S. Jews. 2013. Washington, DC: Pew Research Center, 2013. https://www.pewforum.org/2013/10/01/jewish-americanbeliefs-attitudes-culture-survey/.

A Treasure for my daughter: A reference book of Jewish festivals with menus and recipes.1958. Ed. Bessie W. Batist. Recipe Eds. Sarah Ein, Anne Warshaw, and Mary Davids. Montreal: Ethel Epstein Ein Chapter of Hadassah.

Bahloul, Joelle. 1995. Food practices among Sephardic immigrants in contemporary France: Dietary laws in urban society. Journal of the American Academy of Religion 63 (3): 485-496.

Bahloul, Joëlle. 2016. Jewish foods at the turn of the twenty-first century. In The handbook of food and anthropology, ed. Jacob A. Klein and James L. Watson, 94-114. London: Bloomsbury.

Blech, Zushe Yosef. 2008. Kosher food production, 2nd ed. Hoboken: Wiley-Blackwell.

Borowitz, Eugene B. 1984. The autonomous Jewish self. Modern Judaism 4 (1): 39-56.

Brym, Robert, Keith Neuman, and Rhonda Lenton. 2019. 2018 Survey of Jews in Canada-Final report. Toronto: Environics Institute. https://www.environicsinstitute.org/projects/project-details/ survey-of-jews-in-canada.

Canada Internet Use Survey. 2019. Statistics Canada. https://www150.statcan.gc.ca/n1/daily-quotidien/ 191029/dq191029a-eng.htm.

Cappucci, John. 2020. Believe, pray, obey: Three indicators of religiosity in a Jewish community. Canadian Jewish Studies 30: 115-135.

Cinotto, Simone, and Hasia R. Diner. 2018. Introduction: Jewish foodways in food history and the Jewish diasporic experience. In Global Jewish foodways: A history, ed. Hasia R. Diner and Simone Cinotto, 1-24. Lincoln: University of Nebraska Press.

Cooper, John. 1993. Eat and be satisfied: A social history of Jewish food. Northvale: Jason Aronson. 
Dallam, Marie W. 2014. Introduction: Religion, food, and eating. In Religion, food, and eating in North America, ed. Benjamin E. Zeller, Marie W. Dallam, Reid L. Neilson, and Nora L. Rubel, xvii-xxxii. New York: Columbia University Press.

de Lange, Nicholas. 2010. An introduction to Judaism, 2nd ed. Cambridge: Cambridge University Press.

Deutsch, Jonathan, and Rachel D. Saks. 2009. Jewish American food culture. Lincoln: University of Nebraska Press.

Diamond, Etan. 2002. The kosher lifestyle: Religious consumerism and suburban Orthodox Jews. Journal of Urban History 28 (4): 488-505.

Diner, Hasia R. 2001. Hungering for America: Italian, Irish, and Jewish foodways in the age of migration. Cambridge: Harvard University Press.

Dorff, Elliot N. 2018. Modern Conservative Judaism: Evolving thought and practice. Lincoln: University of Nebraska Press.

Eidinger, Andrea. 2012. Gefilte fish and roast duck with orange slices: A treasure for my daughter and the creation of a Jewish cultural Orthodoxy in postwar Montreal. In Edible histories, cultural politics: Towards a Canadian food history, ed. Franca Iacovetta, Marlene Epp, and Valerie J. Korinek, 189-208. Toronto: University of Toronto Press.

Eisenberg, Ronald L. 2004. The JPS guide to Jewish traditions. Philadelphia: Jewish Publication Society.

Elazar, Daniel J., and Rela Mintz Geffen. 2000. The Conservative movement in Judaism: Dilemmas and opportunities. Albany: State University of New York Press.

Emet ve'emunah: Statement of principles of Conservative Judaism. 1988. New York: Jewish Theological Seminary of America. https://masortiolami.org/wp-content/uploads/2014/03/Emet-VEmunah-State ment-of-Principles-of-Conservative-Judaism.pdf.

Ferris, Marcie Cohen. 2018. Dining the Dixie diaspora: A meeting of region and religion. In Global Jewish foodways: A history, ed. Hasia R. Diner and Simone Cinotto, 291-322. Lincoln: University of Nebraska Press.

Fishkoff, Sue. 2010. Kosher nation: Why more and more of America's food answers to a higher authority. New York: Schocken.

Gates of mitzvah: A guide to the Jewish life cycle. 1979. Ed. Simeon J. Maslin. New York: Central Conference of American Rabbis.

Gross, Rachel B. 2019. Table talk: American Jewish foodways and the study of religion. Religion Compass. https://doi.org/10.1111/rec3.12297.

Horowitz, Roger. 2016. Kosher USA: How Coke became kosher and other tales of modern food. New York: Columbia University Press.

Kaplan, Dana E. 2013. The new Reform Judaism: Challenges and reflections. Lincoln: University of Nebraska Press.

Kaplan, Mordecai M. 1935. Judaism as a civilization: Toward a reconstruction of American-Jewish life. New York: Macmillan.

Kirshenblatt-Gimblett, Barbara. 1987. Recipes for creating community: The Jewish charity cookbook in America. Jewish Folklore and Ethnology 9 (1): 8-12.

Kraemer, David C. 2007. Jewish eating and identity through the ages. New York: Routledge.

Liebman, Charles S. 1965. Orthodoxy in American Jewish life. American Jewish Yearbook 66: 21-97.

Liebman, Charles S. 1973. The ambivalent American Jew: Politics, religion, and family in American Jewish life. Philadelphia: Jewish Publication Society of America.

Merwin, Ted. 2015. Pastrami on rye: An overstuffed history of the Jewish deli. New York: New York University Press.

Neusner, Jacob. 1988. A Religion of pots and pans? Modes of philosophical and theological discourse in Ancient Judaism: Essays and a program. Atlanta: Scholars Press.

Norman, Corrie E. 2012. Food and religion. In The Oxford handbook of food history, ed. Jeffrey M. Pilcher, 409-427. Oxford: Oxford University Press.

Pew Research Center. 2017. In America, does more education equal less religion? https://www.pewfo rum.org/2017/04/26/in-america-does-more-education-equal-less-religion/.

Plaut, Jonathan V. 2007. The Jews of Windsor, 1790-1990: A historical chronicle. Toronto: Dundurn Press.

Robinson, George. 2016. Essential Judaism: A complete guide to beliefs, customs, and rituals. Updated. New York: Atria.

Robinson, Ira. 2007. Rabbis and their community: Studies in the Eastern European Orthodox rabbinate in Montreal, 1896-1930. Calgary: University of Calgary Press. 
Sax, David. 2010. Save the Deli: In search of perfect pastrami, crusty rye, and the heart of Jewish delicatessen. Toronto: Emblem.

Shahar, Charles. 2014. 2011 National household survey analysis: The Jewish population of Canada Part 1 basic demographics Part 2 Jewish populations in geographic areas. Toronto: Jewish Federations of Canada. https://www.jewishcanada.org/nhs-2011.

Shahar, Charles, and Tina Rosenbaum. 2005. Jewish life in greater Toronto: A survey of the attitudes \& behaviours of greater Toronto's Jewish community. Unabridged ed. Toronto: UJA Federation of Greater Toronto. https://www.jewishdatabank.org/content/upload/bjdb/2005_Toronto_Unabridged_ Jewish_Community_Study_Report.pdf.

Sklare, Marshall. 1972. Conservative Judaism: An American religious movement. New York: Schocken.

Statistics Canada. 2017. Windsor, CY [Census subdivision], Ontario and Essex, CTY [Census Division], Ontario (Table). Census profile. 2016 census. Statistics Canada catalogue no. 98-316-X2016001. Ottawa. https://www12.statcan.gc.ca/census-recensement/2016/dp-pd/prof/index.cfm?Lang=E.

Steinberg, Ellen F., and Jack H. Prost. 2011. From the Jewish heartland: Two centuries of Midwest foodways. Urbana, IL: University of Illinois Press.

Talmud Bavli. Trans. A.S. Even-Israel. William Davidson edition. Sefaria. https:/www.sefaria.org/texts/ Talmud/Bavli.

The Jewish study Bible. 2014. 2nd edition. Edited by A. Berlin and M.Z. Brettler. Oxford: Oxford University Press.

The Pittsburg platform-1885. Central Conference of American Rabbis (CCAR). https://www.ccarnet. org/rabbinic-voice/platforms/article-declaration-principles/.

Trojan, Gesa. 2020. The Naomi cook book: A narrative of Canadian Jewish integration. Canadian Jewish Studies 29: 33-56.

Tuchman, Gaye, and Harry Gene Levine. 1993. New York Jews and Chinese food: The social construction of an ethnic pattern. Journal of Contemporary Ethnography 22 (3): 382-407.

Weinfeld, Morton. 2018. Life everyone else but different: The paradoxical success of Canadian Jews, 2nd ed. Montreal: McGill-Queen's University Press.

Publisher's Note Springer Nature remains neutral with regard to jurisdictional claims in published maps and institutional affiliations.

John Cappucci Dr. John Cappucci is the Stephen A. Jarislowsky Chair in Religion and Conflict and Principal and Vice-Chancellor of Assumption University in Windsor, Ontario. His published works have appeared in Canadian Jewish Studies, Fieldwork in Religion, and Journal of Muslim Minority Affairs. 